\title{
Ratio Decidendi Hakim Terhadap Putusan Lepas Dari Segala Tuntutan Hukum (Studi Putusan Nomor: 102/Pid.B/2014/Pn.Kka Tentang Tindak Pidana Penggelapan)
}

\author{
Ratio Decidendi of the Judge Against The Verdict of the Escape From All The \\ Demands of the Law (Studies Verdict No. 102/Pid.B/2014/Pn.Kka. of the \\ Criminal Offence Of Embezzlement)
}

\author{
Erwin Sulaiman \\ Universitas Semilanbelas November Kolaka \\ E-mail: Erwinsulaiman12@mail.com \\ Sabrina Hidayat \\ Pascasarjana Universitas Halu Oleo \\ E-mail: sabrina.hidayat54@yahoo.com \\ Handrawan \\ Pascasarjana Universitas Halu Oleo \\ E-mail: handrawansaranani84@gmail.com
}

\begin{abstract}
This study aims to determine and analyze the Ratio Decidendi of the Judge Against the Verdict of the Escape From All the Demands of the Law In Cases of Embezzlement as well as to determine and analyze the Legal Implications of a Verdict of Escape From All the Demands of the Law.

The research method used in this law research is normative, which examines the study of documents, namely using a variety of data such as Legislation, Court decisions, legal theory, and can be either the opinion of scholars.

Ratio Decidendi of the Judge in a case of embezzlement that is in accordance with the facts-the fact that there basically has been proven, based on the description of the Accused, witness testimony and evidence as well as the fact-legal fact that there are basically proven that the acts committed by the defendant constitutes no action violated the criminal law, but the Judge did not get the belief that the case is a criminal offense, in the concept of the theory of the use of the judge's conviction should only be done as long as not contrary to the Law and the facts-legal facts revealed in the trial.

From the implications of his own law Judge deciding the case that is separated from all the demands of the law, such decision could adversely impact the victim materially, whereas in self the defendant the Verdict of the Judge of the district Court
\end{abstract}


Kolaka is actually beneficial and save yourself the Defendant from the threat of punishment.

Keyword: Ratio Decidendi of the Judge; The Verdict of the Escape From All The Demands of the Law; Embezzlement

\begin{abstract}
Abstrak: Penelitian ini bertujuan untuk mengetahui dan menganalisis Ratio Decidendi Hakim Terhadap Putusan Lepas Dari Segala Tuntutan Hukum Dalam Perkara Penggelapan serta untuk mengetahui dan menganalisis Implikasi Hukum Atas Putusan Lepas Dari Segala Tuntutan Hukum.

Metode penelitian yang digunakan dalam penelitian hukum ini adalah normatifyang mengkaji studi dokumen, yakni menggunakan berbagai data seperti peraturan Perundang-Undangan, keputusan Pengadilan, teori hukum, dan dapat berupa pendapat para sarjana.

Ratio Decidendi Hakim dalam perkara penggelapan yaitu sesuai dengan fakta-fakta yang ada pada dasarnya telah terbukti, berdasarkan keterangan Terdakwa, keterangan saksi dan alat bukti serta fakta-fakta hukum yang ada pada dasarnya terbukti bahwa perbuatan yang dilakukan oleh terdakwa merupakan ada tindakan melanggar hukum pidana, namun Hakim tidak mendapatkan keyakinan bahwa perkara tersebut merupakan sebuah tindak pidana, dalam konsep teori penggunaan keyakinan hakim hanya boleh dilakukan selama tidak bertentangan dengan UndangUndang dan fakta-fakta hukum yang terungkap secara nyata dalam persidangan.

Dari implikasi hukum sendiri Hakim memutus perkara tersebut yaitu lepas dari segala tuntutan hukum, putusan tersebut berdampak merugikan diri korban secara material, sedangkan pada diri terdakwa Putusan Hakim Pengadilan Negeri Kolaka justru menguntungkan dan menyelamatkan diri Terdakwa dari ancaman pemidanaan.
\end{abstract}

Kata kunci: Ratio Decidendi Hakim; Putusan Lepas Dari Segala Tuntutan Hukum; Penggelapan

\title{
PENDAHULUAN
}

Tindak pidana penggelapan di Indonesia saat ini menjadi salah satu penyebab terpuruknya sistem kesejahteraan material yang mengabaikan nilai-nilai kehidupan dalam masyarakat. Kehidupan masyarakat sedikit demi sedikit mulai berubah, penghormatan atas nilai-nilai hukum yang ada mulai bergeser, masyarakat mulai berpikir materialistis dan egois dalam menghadapi kehidupan ini, hal ini juga menyebabkan mulai melemahnya rasa kepercayaan masyarakat terhadap sesama individu. Kecenderungan usaha untuk mencapai kesejahteraan material dengan mengabaikan nilai-nilai kehidupan dalam masyarakat mulai tampak, sehingga mulai banyak bermunculan pelanggaran dan pemanfaatan kesempatan secara ilegal untuk kepentingan diri sendiri tanpa mengabaikan hak-hak dari orang lain serta norma-norma yang ada. Hal ini diperburuk dengan semakin meluasnya tindak pidana penggelapan, dimana tindak pidana penggelapan akan membawa sisi negatif yaitu pelanggaran hak-hak sosial serta lunturnya nilai-nilai 
kehidupan dalam masyarakat ${ }^{1}$.

Menurut Indriyanto Seno $\mathrm{Adji}^{2}$, menguraikan pengertian penyalahgunaan wewenang sebagaimana mengutip pendapatnya Jean Rivero dan Waline dalam kaitannya detournement de pouvoirdenganfreis ermessen, penyalahgunaan wewenang dalam hukum administrasi dapat diartikan dalam 3 (tiga) wujud yaitu: 1) Penyalahgunaan kewenangan untuk melakukan tindakan-tindakan yang bertentangan dengan kepentingan umum untuk menguntungkan kepentingan pribadi, kelompok atau golongan; 2) Penyalahgunaan kewenangan dalam arti bahwa tindakan pejabat tersebut adalah benar diajukan untuk kepentingan umum, tetapi menyimpang dari tujuan apa kewenangan tersebut diberikan oleh undang-undang atau peraturan-peraturan lainnya; 3) Penyalahgunaan kewenangan dalam arti menyalahgunakan prosedur yang seharusnya dipergunakan untuk mencapai tujuan tertentu, tetapi telah menggunakan prosedur lain agar terlaksana. Hal tersebut disebabkan karena kurangnya pertanggungjawaban pidana yang seharusnya dilakukan oleh pelaku tindak pidana penggelapan.

Tindak pidana penggelapan merupakan suatu tindak pidana yang berhubungan dengan kepercayaan dan harta kekayaan. Tindak pidana penggelapan diatur dalam Buku Kedua Bab XXIV Pasal 372, 373, 374, 375, 376, dan 377 KUHP. Penggelapan dengan segala macam bentuknya merupakan suatu jenis tindak pidana yang cukup berat bila dilihat dari akibat yang ditimbulkan dan pengaruhnya terhadap masyarakat, Hal tersebut berbanding lurus dengan upaya pemberantasannya, yang semakin berat untuk dilakukan.

Pemberantasan tindak pidana penggelapan harus dituntut dengan cara yang sesuai dengan yang terdapat di dalam KUHP, serta melibatkan potensi yang ada dalam masyarakat khususnya pemerintah dan aparat penegak hukum.

Penegakkan hukum di Indonesia dilakukan oleh aparat Negara yang berwenang. Aparat Negara yang berwenang dalam pemeriksaan perkara pidana adalah aparat Kepolisian, Kejaksaan, dan Pengadilan. Polisi, Jaksa, dan Hakim merupakan tiga unsur penegak hukum yang masing-masing mempunyai tugas, wewenang, dan kewajiban sesuai dengan Peraturan Perundang-undangan yang berlaku. Aparat penegak hukum merupakan unsur yang menjalankan tugasnya sebagai sub sistem dari sistem peradilan pidana. Para penegak hukum ini masing-masing mempunyai peranan yang berbeda-beda

1 Sudarto, Kapita Selekta Hukum Pidana, Bandung, Alumni, 1998, hlm. 98

2 Oheo K.Haris, Aspek Hukum Pidana Dalam Kaitannya Dengan Perizinan Di Bidang Pertambangan, Yuridika, Volume 29 No 3, September-Desember 2014, hlm. 54. 
sesuai dengan bidangnya. Ketiganya secara bersama - sama mempunyai kesamaan dalam tujuan pokoknya yaitu pemasyarakatan kembali para narapidana.

Penjatuhan sanksi pidana oleh hakim yang terlalu ringan akan memberikan dampak negatif yaitu akan munculnya pelaku - pelaku yang lain untuk melakukan tindak pidana, karena penjatuhan pidana yang relatif ringan oleh hakim, padahal hakim dalam menjatuhkan pidana haruslah menyadari apa makna pemidanaan itu, serta harus menyadari apa yang hendak dicapai dengan ia menjatuhkan sanksi kepada seseorang yang telah melanggar ketentuan Undang-Undang. Hakim juga dalam menetapkan hukum tidak semata-mata hanya menegakkan hukum dari hukum itu sendiri melainkan untuk mengejar kemanfaatan sosial. ${ }^{3}$

Salah satu kasus penggelapan yang terjadi dalam perkara yang diputus Pengadilan Negeri Kolaka Nomor: 102/Pid.B/2014/PN.KKA tentang tindak pidana penggelapan yang dilakukan terdakwa H. Ir. DJONI ROSADI selaku Direktur Utama PT. Dharma Rosadi Internasional setelah sebelumnya Pengadilan Negeri Kolaka memutuskan terdakwa lepas dari segala tuntutan hukum (onslaag van alle rechtvervoolging). Perkara pidana tersebut sebelumnya antara PT. Dharma Rosadi Internasional yang menjalin kerja sama jual-beli dengan Hongkong Silver Basic Group Limited, dimana PT. Dharma Rosadi Internasional bertindak sebagai yang menjual sejumlah Ore Nikel (kandungan hasil tambang nikel) dan pihak Hongkong Silver Basic Group Limited yang bertindak sebagai pembeli sejumlah Ore Nikel, dimana pihak perusahaan tersebut membebankan kepada PT. Dharma Rosadi Internasional untuk wajib menyediakan 55.000 WMT (Lima puluh lima ribu wet metric ton) Ore nikel ke perusahaan Hongkong Silver Basic Group Limited, sesuai dengan kontrak kerja sama yang telah disepakati oleh kedua perusahaan tersebut sesuai dengan waktu yang telah di sepakati bersama, namun sampai batas akhir waktu yang telah di sepakati dalam kontrak kerja sama, PT. Dharma Rosadi Internasional, ternyata belum atau tidak memiliki sejumlah Ore nikel untuk diserahkan ke Hongkong Silver Basic Group Limited. Untuk memenuhi kebutuhan sejumlah Ore nikel tersebut PT. Dharma Rosadi Internasional mengadakan kerja sama dengan CV. Mallibu yang siap menyediakan sejumlah ore nikel tersebut sesuai kebutuhan PT. Dharma Rosadi Internasional, dengan kontrak kerja sama dimana dalam perjanjian kerja sama menyebutkan bahwa PT. Dharma Rosadi Internasional akan membayarkan sesuai dengan harga final yang di berikan oleh Hongkong Silver Basic Group

\footnotetext{
$3 \quad$ Ibid., hlm. 100.
} 
Limited ke PT. Dharma Rosadi Internasional, setelah menerima ore nikel dari CV. Mallibu dan memenuhi kewajiban ke Hongkong Silver Basic Group Limited dan setelah saksi Hamid Talib selaku Direktur CV. Mallibu beberapa kali meminta hasil final penjualan sejumlah Ore nikel yang di maksud, selain pembayaran Ore nikel, selain pembayaran Ore nikel itu sama sekali itu sama sekali tidak ada yang di bayarkan ke saksi Hamid Talib selaku Direktur CV. Mallibu, pada sekitar tahun 2012 Terdakwa mengatakan kepada saksi Hamid Talib bahwa sejumlah Ore nikel tersebut telah ditolak sebab kadar dari kandungan Ore Nikel tersebut jatuh/rendah atau tidak sesuai permintaan sehingga pihak Hongkong Silver Basic Group Limited tidak mau membayar harga ore nikel atau dengan kata lain tidak laku.

Akibat dari perbuatan terdakwa selaku Direktur Utama PT. Dharma Rosadi Internasional, CV Mallibu atau saksi Hamid Talib mengalami kerugian sebesar Rp. 19.800.000.000,- (Sembilan belas milyar delapan ratus juta rupiah) atau jumlah itu.

Putusan Pengadilan Negeri Kolaka Nomor: 102/Pid B/2014/PN.KKA, Jaksa Penuntut Umum menuntut terdakwa berupa pidana penjara selama 3 (tiga) tahun, Menetapkan masa penahanan yang telah dijalani terdakwa di kurangkan seluruhnya dari pidana yang dijatuhkan, padahal menurut keterangan saksi-saksi dan fakta yang terungkap di persidangan sudah memenuhi unsur-unsur yang terkandung dalam Pasal 372 KUHP, sedangkan vonis hukuman yang dijatuhkan oleh hakim kepada terdakwa yaitu putusan lepas dari segala tuntutan hukum (onslaag van alle recht vervolging) pasal 191 ayat 2 Kitab Undang-Undang Hukum Pidana. Jelas sekali di sini Hakim tidak melakukan putusan yang seharusnya sesuai dengan Pasal 372 Kitab Undang-Undang Hukum Pidana tentang penggelapan, dimana dalam pembuktiannya telah memenuhi unsur-unsur penggelapan. Putusan tersebut sepertinya sangat tidak sesuai dengan rasa keadilan bagi korban dan penulis sendiri.

Uraian-uraian di atas menarik perhatian penulis untuk diteliti lebih lanjut mengenai perkara tindak pidana penggelapan yang diputus lepas dari segala tuntutan hukum yang pada dasarnya telah memenuhi unsur-unsur penggelapan dalam perkara tersebut. Untuk itu, penulis tertarik untuk melakukan penelitian dengan judul: Ratio Desidendi Lepas Dari Segala Tuntutan Hukum Tentang Tindak Pidana Penggelapan. 


\section{ANALISIS DAN PEMBAHASAN}

\section{Ratio Decidendi Hakim Terhadap Putusan Lepas Dari Segala Tuntutan Hukum Dalam}

\section{Perkara Penggelapan}

Pertimbangan hakim adalah dasar-dasar yang menjadi pertimbangan dalam membuat suatu putusan. Hakim dalam membuat putusan haruslah memperhatikan unsur-unsur subjektif dan unsur-unsur objektifnya. Apabila unsur-unsur tersebut terpenuhi, selanjutnya hakim mempertimbangkan hal-hal yang dapat meringankan dan memberatkan putusan yang akan dijatuhkannya nanti. Pertimbangan hakim dinilai dari faktor hukum dan nonhukum yang kesemuanya itu haruslah disertakan dalam putusan.

Jika suatu putusan pengadilan tidak cukup mempertimbangkan (Ovoldoende Gemotiveerd) tentang hal-hal yang dirasa adanya kejanggalan yang menyebabkan matinya akal sehat, putusan pengadilan yang tidak logis akan dirasakan pula oleh masyarakat yang paling awam, karena putusan pengadilan menyangkut nurani kemanusiaan ${ }^{4}$. Penegak hukum bukanlah budak kata-kata yang dibuat pembentuk undang-undang, melainkan lebih dari itu mewujudkan keadilan berdasarkan norma hukum dan akal sehat.

Dalam menjatuhkan pidana, kiranya rumusan Pasal 58 (Pasal 52) Naskah Rancangan KUHPidana (baru) hasil penyempurnaan Tim Intern Departemen Kehakiman, dapat dijadikan referensi. Disebutkan bahwa dalam penjatuhan pidana hakim wajib mempertimbangkan hal-hal berikut yaitu ${ }^{5}$ Kesalahan pembuat tindak pidana, Motif dan tujuan melakukan tindak pidana, Cara melakukan tindak pidana, Sikap batin pembuat tindak pidana, Riwayat hidup dan keadaan sosial ekonomi pembuat tindak pidana, Sikap dan tindakan pembuat sesudah melakukan tindak pidana, Pengaruh pidana terhadap masa depan pembuat tindak pidana, Pandangan masyarakat terhadap tindak pidana yang dilakukan, Pengurus tindak pidana terhadap korban atau keluarga korban; dan Apakah tindak pidana dilakukan dengan berencana.

Berdasarkan hasil penelitian Penulis terhadap Putusan Nomor 102/Pid.B/2014/PN.KKA masih menyisakan banyak problematika hukum dimana hakim mengabaikan fakta-fakta hukum yang terungkap dalam sidang Pengadilan tetapi Hakim lebih bersandar terhadap keyakinannya sedang diketahuinya bahwa unsur penggelapan

\footnotetext{
4 M. Syamsuddin. Konstruksi Baru Budaya Hukum Hakim Berbasis Hukum Progresif, Cetakan Kedua, Jakarta: Kencana, 2012, hlm. 85-86.

5 Bambang Waluyo, Pidana dan Pemidanaan, Jakarta: Sinar Grafika, 2008, hlm. 91.
} 
telah terpenuhi. Akibat dari pengabaian atas fakta-fakta hukum hakim memutus perkara tersebut dengan putusan lepas dari segala tuntutan hukum.

Sebelum penulis menguraikan analisis akan putusan tersebut maka akan diuraikan rentetan analisis terhadap surat tuntutan jaksa penuntut umum demi memperoleh kebenaran materiil dalam Putusan Nomor 102/Pid.B/2014/PN.KKA.

Dalam tuntutan jaksa penuntut umum telah menguraikan bahwa terdakwa tetap berada di dalam tahanan dan di pidana penjara dengan masa hukuman selama 3 tahun, berdasarkan dengan pasal 372 tentang penggelapan, hal ini merupakan upaya hukum yang di lakukan oleh pihak korban atas tindak pidana penggelapan yang di lakukan oleh terdakwa terhadap diri korban yang di nilai merugikan dari aspek material dari perusahaan CV. Mallibu milik korban.

Dari upaya Jaksa Penuntut Umum tersebut yang menilai bahwa terdakwa telah terbukti melakukan tindak pidana penggelapan yang dapat di lihat atau di buktikan berdasarkan unsur-unsur penggelapan dari bukti yang ada, sehingga terdakwa harus mempertanggungjawabkan atas tindak pidana penggelapan yang di dakwakan terhadap dirinya, hal ini merupakan suatu proses hukum yang memiliki dasar kuat dalam hal penetapan tindak pidana penggelapan yang di dasari dari unsur-unsur penggelapan di dalam Kitab Undang-Undang Hukum Pidana.

Penulis sendiri berpandangan bahwa proses hukum dalam tindak pidana dapat saja di lakukan apabila pembuktian berdasarkan unsur-unsur tindak pidana itu terpenuhi di muka sidang, melalui upaya Jaksa Penuntut Umum dalam pembelaannya atas diri korban melalui pembuktian unsur-unsur yang terkandung dalam tindak pidana penggelapan Pasal 372 Kitab Undang-Undang Hukum Pidana merupakan upaya hukum yang sangat bermanfaat bagi diri korban yang ingin menyampaikan keluhan hukumnya atas dampak kerugian yang di timbulkan terhadapnya berupa kerugian yang bersifat material, tuntutan Jaksa Penuntut Umum dalam hal ini adalah merupakan hal yang akan memberikan efek jerah terhadap pelaku tindak pidana.

\section{Implikasi Hukum Terhadap Putusan Lepas Dari Segala Tuntutan Hukum Nomor: 102/Pid.B/2014/Pn.Kka}

Sebagaimana dakwaan Penuntut Umum dalam pasal 372 tindak pidana penggelapan yang dalam pertimbangan hakim menerangkan bahwa perbuatan terdakwa sebagaimana dalam fakta-fakta persidangan telah terbukti sesuai dengan unsur-unsur penggelapan pasal 372, 
akan tetapi hakim tidak memiliki keyakinan atas pokok dasar perjanjian yang di anggapnya adalah termasuk dalam rana perdata, meskipun unsur-unsur tindak pidana telah sesuai dan terbukti di muka persidangan.

Yang pada akhirnya Majelis hakim memutus perkara tersebut lepas dari segala tuntutan hukum (onslaag van alle recht vervolging) dalam pasal 191 ayat 2, KUHAP yang menyatakan jika pengadilan berpendapat bahwa perbuatan yang didakwakan kepada terdakwa terbukti, namun perbuatan tersebut bukan merupakan suatu tindak pidana, hal ini tentu tidak relevan dengan Pasal 183 Undang-undang Nomor 8 tahun 1981 tentang Kitab Undang-Undang Hukum Acara Pidana (KUHAP) selengkapnya berbunyi: "Hakim tidak boleh menjatuhkan pidana kepada seseorang kecuali apabila sekurang-kurangnya dua alat bukti yang sah ia memperoleh keyakinan bahwa suatu tindak pidana benar-benar terjadi dan bahwa terdakwalah yang bersalah melakukannya", dimana dalam hal ini jelas semua bukti berdasarkan alat bukti serta unsur-unsur yang mencakup tindak pidana penggelapan sesuai dengan dakwaan Jaksa Penuntut Umum menurut hakim secara nyata adalah sebuah tindak pidana dalam hal ini merupakan tindak pidana penggelapan namun persoalan keyakinan hakim dalam memutuskan perkara yang dalam pertimbangannya semua unsur-unsur yang terkandung dalam tindak pidana penggelapan telah terpenuhi menjadi salah satu hal yang menarik bagi peneliti untuk mengkaji hal tersebut dan memastikan bahwa telah terjadi kekeliruan oleh hakim terhadap putusan lepas dari segala tuntutan hukum di pengadilan negeri Kolaka.

Berdasarkan implikasi hukum atau dampak hukum yang ditimbulkan atas perbuatan terdakwa yang menyebabkan kerugian sejumlah USD. 400.000,- (empat ratus ribu US Dolar) atau kurang lebih Rp. 19.800.000.000,- (sembilan belas milyar delapan ratus juta rupiah), dan atas pertimbangan hakim mengenai perkara tersebut yang beranggapan bahwa perbuatan tersebut terbukti tetapi bukan merupakan suatu tindak pidana maka hakim pengadilan negeri Kolaka memutus perkara tersebut lepas dari segala tuntutan hukum.

\section{KESIMPULAN}

Ratio Decidendi Hakim dalam perkara penggelapan yaitu sesuai dengan fakta-fakta yang ada pada dasarnya telah terbukti, berdasarkan keterangan Terdakwa, keterangan saksi dan alat bukti serta fakta-fakta hukum yang ada pada dasarnya terbukti bahwa perbuatan yang dilakukan oleh terdakwa merupakan ada tindakan melanggar hukum pidana, namun 
Hakim tidak mendapatkan keyakinan bahwa perkara tersebut merupakan sebuah tindak pidana, dalam konsep teori penggunaan keyakinan hakim hanya boleh dilakukan selama tidak bertentangan dengan Undang-Undang dan fakta-fakta hukum yang terungkap secara nyata dalam persidangan.

Dari implikasi hukum sendiri Hakim memutus perkara tersebut yaitu lepas dari segala tuntutan hukum, putusan tersebut berdampak merugikan diri korban secara material, sedangkan pada diri terdakwa putusan hakim pengadilan negeri Kolaka justru menguntungkan dan menyelamatkan diri Terdakwa dari ancaman pemidanaan.

\section{Daftar Pustaka}

\section{Buku}

Sudarto. Kapita Selekta Hukum Pidana, Bandung: Alumni, 1998.

Syamsuddin, M. Konstruksi Baru Budaya Hukum Hakim Berbasis Hukum Progresif, Cetakan Kedua, Jakarta: Kencana, 2012.

Waluyo, Bambang. Pidana dan Pemidanaan, Jakarta: Sinar Grafika, 2008.

\section{Peraturan Perundang-Undangan}

Undang-Undang Dasar Negara Republik Indonesia Tahun 1945.

Undang-Undang Nomor 1 Tahun 1946 Tentang Kitab Undang-Undang Pidana Indonesia. Undang-Undang Nomor 8 Tahun 1981 tentang Kitab Undang-Undang Hukum Acara Pidana.

\section{Jurnal}

Haris, Oheo K., “Aspek Hukum Pidana Dalam Kaitannya Dengan Perizinan Di Bidang Pertambangan", Yuridika, Volume 29 No 3, September-Desember 2014. 